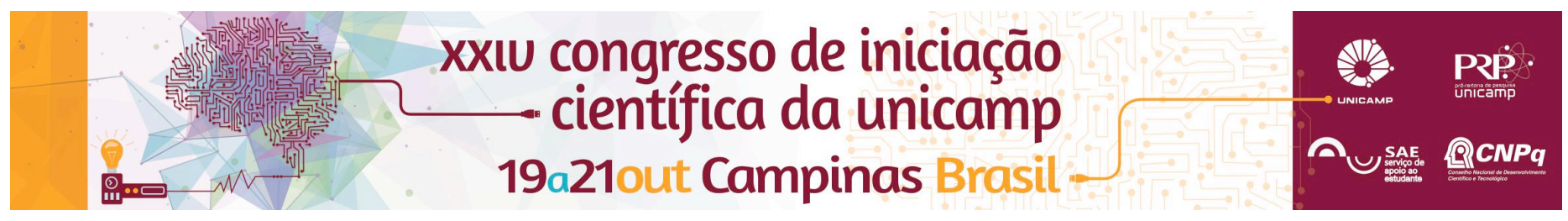

\title{
Evolução do desemprego no Brasil nas últimas décadas
}

\author{
Natália Afonso Corrêa da Silva*, Carlos Salas
}

\section{Resumo}

O presente artigo pretende analisar a variação da taxa de desemprego do Brasil nas últimas décadas, partindo do conceito e história do desemprego e dados do IBGE e PNAD. Passaremos por algumas correntes de pensamento econômico, e sua importância nos respectivos períodos. A análise será pautada nos motivos que fizeram com que o país, mesmo com baixas taxas de desemprego, não tivesse uma "homogeneização social", possuísse um mercado de trabalho de baixa qualificação e condições precárias, principalmente para as mulheres, os negros e os jovens brasileiros.

\section{Palavras-chave: Desemprego, Brasil, Mercado de trabalho}

\section{Introdução}

O intuito desse trabalho era chegar a um conceito de desemprego a ser utilizado e analisar como ele tomou a forma que tem hoje. Depois, demos uma visão geral do desemprego e como ele avançou mundialmente. Com isso, pudemos colocar a forma como ele se expressou no Brasil nas décadas passadas e como tem se expressado nos dias atuais. Enfatizamos o papel das crises na variação do desemprego, e como as políticas governamentais podem amenizá-la. Finalmente, coletamos dados da PNAD e IBGE para analisarmos, e podemos tirar conclusões sobre a evolução do desemprego brasileiro.

\section{Resultados e Discussão}

A primeira parte do projeto consistiu em estudar o significado da palavra "desemprego", enfatizando o desemprego aberto ou involuntário, que só teve origem em um certo momento da história. Utilizamos também uma crítica ao uso da palavra "desemprego" para países em desenvolvimento, que uma menor taxa não significa melhores condições do mercado de trabalho.

$\mathrm{Na}$ segunda parte serviu analisamos a evolução do desemprego no mundo em diferentes épocas, e como ele se divide em relação às regiões, gêneros, raças e idades. Posteriormente, analisamos o desemprego no Brasil, um país em desenvolvimento, e nos deparamos com grandes problemas sociais por trás do desemprego, como o trabalho informal, o subemprego e a ilegalidade. Finalmente, através dos dados do IPEA e IBGE, coletados na PME (Pesquisa Mensal de Emprego) analisamos as taxas anuais e mensais de desemprego, ocupação e da (População Economicamente Ativa). Enfatizamos o período de 2003 a 2008, que o desemprego diminuiu progressivamente, e em 2008 com a crise que se manteve estável, devido a políticas governamentais anticíclicas, de incentivo ao comércio e crescente gasto público.

Tabela 1. Taxa de desemprego no Brasil (\%) - IPEA

\begin{tabular}{|r|c|c|c|c|c|c|c|}
\hline 1992 & 1993 & 1994 & 1995 & 1996 & 1997 & 1998 & 1999 \\
\hline 7,2 & 6,8 & & 6,66 & 7,59 & 8,46 & 9,75 & 10,44 \\
\hline 2000 & 2001 & 2002 & 2003 & 2004 & 2005 & 2006 & 2007 \\
\hline & 10,06 & 9,88 & 10,48 & 9,73 & 10,21 & 9,23 & 8,93 \\
\hline 2008 & 2009 & 2010 & 2011 & 2012 & 2013 & 2014 & \\
\hline 7,79 & 9,05 & & 7,29 & 6,73 & 7,15 & 7,54 & \\
\hline
\end{tabular}

\begin{tabular}{|c|c|c|c|}
\hline Brasil & 5,2 (out) & Grécia & 27,6 (jul) \\
\hline África do Sul & 24,7 (set) & Hungria & 9,8 (set) \\
\hline Alemanha & 6,9 (out) & Índia & 9,9 (2012) \\
\hline Colômbia & 9,0 (set) & Itália & 12,5 (set) \\
\hline Espanha & 26,6 (set) & Polônia & 13,0 (out) \\
\hline Estados Unidos & 7,3 (out) & Suécia & 7,5 (set) \\
\hline França & 11,1 (set) & Turquia & 9.3 (jul) \\
\hline
\end{tabular}

Figura 1. Desemprego por país (em \%) - 2013

\section{Conclusões}

Após todo o estudo, pudemos concluir que apesar do desemprego ser mundial, cada país possui suas peculiaridades. O Brasil, apesar de possuir uma menor taxa de desemprego em relação aos demais países analisados - como mostra a Figura 1 -, não significa que possui melhores condições no mercado de trabalho, mas que as pessoas não podem ficar muito tempo sem emprego'. As mulheres e jovens são os que possuem maiores taxas de desemprego no país. Isso diferencia o Brasil dos países desenvolvidos, e não pode ser interpretado da mesma forma.

\section{Agradecimentos}

Eu gostaria de agradecer à UNICAMP pela oportunidade de refinar meus conhecimentos sobre o desemprego no Brasil, aprender muito e ler autores brilhantes.

${ }^{1}$ UDALL, Alan T.; SINCLAIR, Stuart (1982). The 'Luxury Unemployment' Hypothesis: A Review of Recent Evidence. World Development Journal; Elsevier Publishers

WOLFF, Edward N. (2009). Proverty and Income Distribution, $2^{\text {a }}$ ed., WileyBlackwell; Massachusetts - EUA.

GARRET, John A. (1978). Unemployment in History: Economic thought and Public Policy. $1^{\circ}$ ed, Harper \& Row Publishers; EUA.

POCHMANN, Marcio. O emprego no desenvolvimento da nação. São Paulo, SP: Boitempo, 2008. 238 p., il. (Mundo do trabalho). 